\title{
Rites of Passage: Mortuary Practice, Population Dynamics, and Chronology at the Carrowkeel Passage Tomb Complex, Co. Sligo, Ireland
}

\author{
By THOMAS KADOR ${ }^{1}$, LARA M. CASSIDY ${ }^{2}$, JONNY GEBER ${ }^{3}$, ROBERT HENSEY ${ }^{4}$, PÁDRAIG MEEHAN ${ }^{5}$, and \\ SAM MOORE ${ }^{6}$
}

\begin{abstract}
[ABS]The first detailed investigation of the human remains from the Carrowkeel passage tomb complex since their excavation in 1911 has revealed several new and important insights about life, death, and mortuary practice in Neolithic Ireland. Osteological analysis provides the first conclusive proof for the occurrence of dismemberment of the dead at Irish passage tombs, practised contemporarily with cremation as one of a suite of funerary treatments. The research also highlights changes in burial tradition at the complex over the course of the Neolithic. Providing a chronology for these changes allows them to be linked to wider trends in monument construction, which may relate to changes in both land use and climate during the period. Multi-isotope analysis hints at the presence of non-local individuals among the interred and the possible existence of different food sourcing areas at the onset of the later Neolithic period. Preliminary results from ancient DNA sequencing of six individuals from Carrowkeel provide evidence for the genetic ancestry of Irish Neolithic populations, demonstrating their Anatolian origins and links along the Atlantic façade.
\end{abstract}

Keywords: Neolithic, body processing, dismemberment, isotope analysis, aDNA, chronological modelling, passage grave, Ireland

On 14 April 1911, a team assembled by R.A.S. Macalister (1870-1950), Professor of Celtic Archaeology at University College Dublin, commenced archaeological investigations at Carrowkeel, Co. Sligo, Ireland. Over 18 days, between April and October, they investigated 14 stone cairns (referred to as 'carns'). They excavated eight of these, with seven revealing internal chambers, containing a combination of cremated and unburnt human and animal bone as well as a range of objects, including bone pins, beads, and pottery (Macalister et al. 1912; Hensey et al. 2014). The team published their findings in the Proceedings of the Royal Irish Academy the following year (Macalister et al. 1912). This publication included a brief report on the human remains by Alexander Macalister (1844-1919), Professor of Anatomy at the University of Cambridge and father of R.A.S. Macalister (Hensey et al. 2014; Meehan \& Hensey in press). After the 1912 publication, the remains saw no further study until their chance rediscovery in 2001-02 at the Duckworth Laboratory - now the Leverhulme Centre for Human Evolutionary Studies (LCHES) - in Cambridge by Alison Sheridan, Principal Curator at the National Museum of Scotland (Hensey et al. 2014; Meehan \& Hensey in press). Even thereafter, the collection was not subjected to modern investigative techniques for another decade until the present study was established in 2013 (see Kador et al. 2015b).

Given the fact that it had not been worked on throughout the 20th century, the Carrowkeel assemblage presented a unique opportunity to examine the remains using state-of-the-art scientific approaches. More specifically, the present study chose to employ a methodology combining osteological analysis, AMS radiocarbon dating, isotope analysis, and, latterly, also included ancient DNA (aDNA) sequencing to address the following key questions in Irish and European passage tomb research;

1. How does the specific evidence from Carrowkeel relate to population dynamics and burial practices at other passage tombs in Neolithic Ireland and beyond?

2. What is the chronology of activity, and in particular the sequence of depositions, at the complex?

3. What is the demographic profile, genetic ancestry and geographical origin of the people whose remains were placed inside the tombs at Carrowkeel?

After providing a brief background on the Carrowkeel landscape and previous research on the complex, the paper will introduce the analyses conducted on the remains with a view to expanding upon the strategy and methods used for addressing these three questions.

\section{[H1]CARROWKEEL IN CONTEXT}

[H2]Background and location

Carrowkeel comprises a group of megalithic monuments centred on the Bricklieve Mountains, a distinctive karst upland to the west of Lough Arrow in south-east Co. Sligo. There, a closely spaced central agglomeration of cairns (over about $2 \mathrm{~km}^{2}$ ) is surrounded by a set of outlying monuments, making up a total of 27 passage tomb and probable passage tomb tradition sites within a $c .6 \mathrm{~km}$ radius (Table 1; Hensey et al. 2014, 11-13, fig. 3), thus covering an area of roughly100 $\mathrm{km}^{2}$ (Fig. 1). Recent literature has considered the most appropriate name for these groups of tombs. Following Bergh (1995), 'Carrowkeel-Keshcorran complex' is most commonly used, as the majority of the cairns are situated around these two elevated zones. The name 'Lough Arrow complex' has also been discussed as a way of incorporating other passage tomb tradition sites in the region, including Ardloy, Suigh Lughaidh (Seelewey), and Heapstown (Hensey et al. 
2014, 7-13). However, for simplicity (and continuity, following the terminology used by the 1911 excavation team) in this publication the terms 'Carrowkeel' or 'Carrowkeel complex' will be employed.

Most of the tombs within the Carrowkeel group have been classed as belonging to the Irish passage tomb tradition. Passage tombs, alongside court and portal tombs, represent one of the three traditionally discussed major Irish Neolithic tomb types (Waddell 1998; Shee Twohig 1990; Cooney 2000). As the morphology of the Carrowkeel tombs is outlined in detail elsewhere (Egan et al. 2005), it will not be discussed further here. The core monument cluster, primarily located within the townland of Carrowkeel, contains the 14 sites on which Macalister and colleagues focused, including the eight cairns they excavated. These are perched atop three limestone ridges which grant them a commanding position in the landscape and great visibility from the surrounding lowlands, making Carrowkeel one of Europe's most striking megalithic landscapes (Fig. 2). Carboniferous Limestone dominates the area surrounding Carrowkeel, however, there are also areas of older (Devonian and Ordovician) geology in the wider north-western region of Ireland (Fig. 3; Harney et al. 1996; Holland 2003; McAteer \& Parkes 2004). This is of particular relevance for the interpretation of the results of the strontium isotope analysis.

\section{[H2]Key issues in Irish passage tomb research}

The relatively small number of individuals - accounted for archaeologically - from Irish passage tombs, in relation to the size of the communities involved in their construction and the extended duration of activities conducted there, has prompted many discussions regarding their meaning and use (Fleming 1973; Herity 1974; O'Kelly 1989; Shee Twohig 1990; Bradley 1998; Cooney 2000; Buckley et al. 2017). In particular, the question concerning who the people chosen for deposition in passage tombs were, and on what basis they were selected, remains a contentious topic. Yet the consensus view seems to be that Neolithic communities were highly selective as to who they interred in their tombs (Cooney \& Grogan 1994; Cooney 2000; Waterman \& Thomas 2011).

The paucity of human remains recovered from Irish passage tombs (Murphy et al. 2010; Buckley et al. 2017; Cooney 2017), and the historical nature of many investigations, also means that only a limited amount of reliable dating evidence is available. Consequently, the wider chronology of these sites remains a matter of debate (Cooney et al. 2011; Bayliss \& O’Sullivan 2013; Bergh \& Hensey 2013; Hensey 2015; Schulting et al. 2017a; 2017b). In this context, the possibility of obtaining a series of new radiocarbon dates from a major passage tomb complex such as Carrowkeel represents an excellent opportunity to further refine these chronologies.

Given the available burial assemblages from Irish passage tombs, there has been a long-standing perception that cremation was the predominant funerary rite practised at these sites (Herity 1974; Cooney \& Grogan 1994; Cooney 2000). However, this has recently become a matter of debate (Cooney 2014; 2016; 2017); a debate to which the analysis of the Carrowkeel remains can make a significant contribution.

\section{[H2]Connecting the bones to the cairns}

One cornerstone of this project rested on establishing definitively the relationship between the human remains currently curated at the LCHES, Cambridge and their original context within the Carrowkeel complex, as discussed in the 1912 report (Meehan \& Hensey in press). During analysis of the material in 2012 it became apparent that the tomb labelling systems associated with the collection at the LCHES did not match that published by Macalister and colleagues in 1912. Therefore, it was critical to ascertain from which of the Carrowkeel monuments the bones housed at the LCHES originated. A detailed account of the intricate process of unravelling the labelling systems is provided elsewhere (Meehan \& Hensey in press) and only the most salient points will be summarised here. It appears that two monument identification systems were employed for the cairns; an alphabetical and a numerical one (Table 2). In the excavation report published in 1912, Macalister and colleagues $(1912,321)$ describe the alphabetical labelling of 14 individual sites (which is still used today). The numerical system, primarily associated with the material curated in Cambridge, applied only to the eight excavated monuments. The initial link between the two systems was provided by a series of photographs made by William A. Green during the team's second period of excavation at Carrowkeel in June 1911 (Fig. 4). A process of elimination and comparison of the contents of boxes at the LCHES allowed the affinity of the remaining labels to be ascertained to a high degree of probability. They show that the bone material at the LCHES originated from no more than seven (and no less than six) monuments (Table 2). Establishing the relationship between the alphabetic system presented in the 1912 publication and the numeric labels associated with the human remains at the LCHES has been vital to understanding their spatial distribution at the Carrowkeel complex. This in turn has been essential for the analyses and interpretation of the remains described in the following sections.

\section{[H2]Methods and techniques}

\section{[H1]ANALYSES OF THE REMAINS}

Four key investigative techniques were brought together to study the remains: osteological analysis; AMS radiocarbon dating; isotope analysis; and aDNA sequencing. The sampling strategies and analytical methodologies employed for each of these methods are outlined in detail in Appendix S1 and will be briefly summarised here. Macroscopic osteological analysis of cremated and unburnt human and animal remains was carried out following standard osteological protocol (Schmid 1972; Buikstra \& Ubelaker 1994; Brickley \& McKinley 2004; English Heritage 2014). It focused on demographic (age-at-death and sex), metric (including stature), and taphonomic analysis of both the human and animal bone assemblages (Geber et al. 2016; 2017). 
AMS radiocarbon dating was conducted on 38 samples: 29 on human bone (from 27 individuals); eight on cremated red deer antler and one on a canid (dog or wolf) tooth. The non-cremated portion of these samples $(n=24)$ was also analysed for stable carbon and nitrogen isotopes $\left(\delta^{13} \mathrm{C}\right.$ and $\left.\delta^{15} \mathrm{~N}\right)$. The details of these samples, the resulting dates, calibrations, and isotope results are presented in Table 3.

Fifteen human dental enamel samples (from 14 individuals) and one from a canid (see above) were analysed for strontium, oxygen, and carbon isotopes, following published protocols (Kador et al. 2015a; Chenery et al. 2012 for oxygen and Triantaphyllou et al. 2015 for strontium). To establish a better idea of the (strontium) isotopic background signature in the local biosphere, two samples of crown dentine (Montgomery et al. 2007; Montgomery 2010; Ditchfield 2014), and four vegetation samples - comprising clippings of twigs - from the Carrowkeel region were analysed for strontium (Fig. 3; see Table 7).

The remains of eight individuals were subjected to ancient DNA (aDNA) extraction and Illumina sequencing, following standard protocols (Yang et al. 1998; MacHugh et al. 2000; Meyer \& Kircher 2010). With full population genetic analysis still ongoing, the results discussed here are preliminary.

\section{[H2] Osteological analysis and human population characteristics}

The human bone assemblage from Carrowkeel comprises $9.7 \mathrm{~kg}$ unburnt and $5.7 \mathrm{~kg}$ cremated commingled remains (Geber et al. 2016), representing a minimum number (MNI) of 18 unburnt and 22 cremated individuals. Quantified together the cremated and unburnt material give an MNI of 29, an estimate very close to the 31 individuals originally estimated by A. Macalister (Macalister et al. 1912). In greater detail they represent a minimum of one neonate (<4 weeks), one infant (1-11 months), two young children (1-4 years), four older children (5-12 years), two adolescents (13-19 years), and 19 adults ( $\geq 20$ years). This proportion of $35 \%$ juveniles/non-adults is higher than that generally found at Irish passage tombs but is virtually identical with the ratio at Knowth (Buckley et al. 2017; Cooney 2017, 391). Of the adults, nine could be sexed as males and four as females (Geber et al. 2016, table 2) which is in keeping with a general trend of males seemingly being over-represented at Irish passage tombs (Cooney \& Grogan 1994; Cooney 2017).

While A. Macalister stated that 'many of the people buried in the carns [sic] were under twenty-five years of age' (Macalister et al. 1912, 343) the presence of older individuals can be ascertained from progressed stages of attritional tooth wear in at least seven dentitions (three males, one female, and three of indeterminable sex).

Additionally, the right half of a male mandible was completely edentulous (9/9), which may indicate an advanced age of that individual with age-related ante-mortem tooth loss. This particular mandible, however, also display a possible healed fracture line located horizontally across the anterior surface of the medial portion of the ramus, just anterior of the right mental foramen, which suggests that some of the tooth-loss was a consequence of direct trauma.

In addition to this case of possible facial trauma, the palaeopathological evidence revealed incidences of joint disease and ossification of ligaments. The spines from a minimum of two individuals $(33.33 \% ; 2 / 6)$ displayed evidence of degenerative joint disease and osteoarthritis, intervertebral osteochondrosis, vertebral osteophytosis, and Schmorl's nodes which, in both of these cases, should be regarded as normal wear-and-tear as a consequence of ageing (Gallucci et al. 2009). Among the extra-spinal joints, however, there was a cremated fragment of a scapula from Cairn $H$ that displayed a severe case of joint degeneration of the left shoulder joint. The joint surface of the glenoid cavity was completely worn and displayed patches of eburnation and build-up of marginal osteophytes, which suggests either trauma or excessive repetitive activity as a likely aetiology (Taylor \& Laurencin 2009). Other pathological changes relating to activity were indicated from bony enthesophytes on the calcaneal attachment of the Achilles tendon, on a right calcaneus recovered from Cairn $\mathrm{K}$. The Achilles tendon attaches the soleus and gastrocnemius muscles to the heel of the foot, and the pathology suggests that this individual undertook constant pulling on the tendon during plantarflexion of the foot and flexion of the knee joint. This may be as a consequence of repetitive squatting postures, which is further indicated from the primarily platycnemic (laterally flattened) shapes of the measurable tibiae (Geber $e t$ al. 2016). Squatting facets were also present on one left and two right tibiae from the same context, which had already been pointed out by A. Macalister (Macalister et al. 1912, 342). No evidence of infectious or metabolic disease was observed in the remains. The only dental pathologies observed were calculus deposits on 81 observable permanent teeth $(95.29 \% ; 81 / 85)$ in at least 13 dentitions $(100.00 \% ; 13 / 13)$, ante-mortem loss of ten teeth $(2.28 \% ; 10 / 438)$ in a minimum of one dentition $(8.33 \% ; 1 / 12)$, and periodontal disease in five mandibles $(41.67 \% ; 5 / 12)$.

The people interred in the Carrowkeel monuments appear to conform to a normal variation as expected for an Irish Neolithic population, both in terms of their physical build and skeletal health (Murphy et al. 2010; Roberts \& Cox 2003; Cahill \& Sikora 2011; O’Donnabhain \& Tesorieri 2014). Metric analysis indicates that their stature ranged from $154 \mathrm{~cm}(5 \mathrm{ft} 1 / 2$ in) to $181 \mathrm{~cm}(5 \mathrm{ft} 11 \mathrm{in}$; Geber et al. 2016, table 3).

\section{[H1]EVIDENCE OF POST-MORTEM BODY PROCESSING}

Close macroscopic examination revealed cut-marks on at least 12 bones, deriving from a minimum of one adult individual. The bones were present in Cairns $\mathrm{H}, \mathrm{K}$, and from a mixed sample from unknown contexts. They revealed an aspect of the post-mortem funerary rite in the Neolithic which, until this discovery, has rarely been reported from Irish osteoarchaeological evidence, with only two other examples from Carrowmore, Co. Sligo and Millin Bay, Co. Down respectively (Burenhult 1998; 2003; Murphy 2003; Murphy et al. 2010). The distribution of the cut-marks suggests that they had been inflicted as part of a dismemberment process rather than defleshing, although the possibility that the latter was also performed cannot be rejected. The joints affected were the shoulder, elbow, hip, knee, and ankle/foot, and the 
precision and consistency of the cuts indicate that they were undertaken with particular anatomical knowledge and skill that targeted specific tendons and ligaments (Fig. 5; Geber et al. 2017).

\section{[H1]ANIMAL REMAINS}

The skeletal material from Carrowkeel contains a significant proportion of animal remains (Table 4), including six identified mammal species; cattle, caprovine (sheep/goat), pig, red deer, canid (dog/wolf), and hare, as well as a single bone fragment from a gull. The 1911 excavation report mentions the presence of worked bear bone in Cairn G (Macalister et al. 1912, 337). While no evidence for bear bone was found during analysis, this comment may refer to a worked bone pin (E624.2), in the National Museum of Ireland, marked in ink with 'Fibula, Bear, Cairn I Central Recess'. It is, however, not possible to identify this specimen (from Cairn G) to animal species based on morphology alone. Some of the bone fragments from smaller animals in the unburnt material may represent natural inclusions; the presence of cremated animal remains, however, points to their intentional use as part of the burial rite. The most conclusive evidence for this comes from the 39, mainly cremated, large mammal (possibly red deer) bone and antler fragments (Fig. 6). These include an unburnt antler fragment from Cairn E and seven cremated antler fragments and two cremated cranial bones from (the right-hand recess of) Cairn K, which suggests that a complete or partial red deer cranium with antlers still attached may have been placed on a cremation pyre (Serjeantson 2011, 71). The contents of this monument also included a cremated fragment of the femur of a large mammal, which may also be red deer. Additionally, a total of 28 cremated red deer antler fragments were present among the material that could not be attributed to a particular cairn among the seven monuments from which bone is present at the LCHES. These antler samples provide important evidence for the dating of the earliest activity at Carrowkeel, which will be discussed in the next section.

\section{[H2]Chronology}

All the 38 samples obtained for dating from the 1911 excavations returned Neolithic dates (Table 3). More specifically, (at 95.4\% confidence) they range between 3641-3381 and 2834-2469 cal BC, thus spanning the Middle and Late Neolithic periods (Cooney et al. 2011; Whitehouse et al. 2014; McLaughlin et al. 2016). These dates are in good agreement with two recently dated human skull fragments from Cairn G, discovered some 50 years after the 1911 excavations (Table 5; Lucas 1963, 124; Hensey et al. 2014, table 5). Somewhat surprisingly, no Bronze Age or later samples were identified among the dated human and animal remains. This is despite evidence for Early Bronze Age bowl and vase tradition pottery in Cairns B, K, and O from the 1911 excavations, as well as Cairn V, excavated in the 1960s (Rynne 1969). There are also two late 3rd millennium BC radiocarbon dates from Cairns $\mathrm{M}$ and V (on human tooth and cremated bone respectively; Table 5; Waddell 1990; Bergh 1995; Brindley 2007; Hensey et al. 2014).

As the 1911 excavation team left no stratigraphic records, contextualising the recovered remains is problematic. This in turn makes a detailed chronological analysis of the complex difficult to achieve. However, a simple model that assumes all the burials took place as part of a single phase of depositions can be suggested (Fig. 7; Appendix S2; Table S1); including all the dates obtained on human and animal (largely cremated antler) remains from the 1911 excavation and the two samples from Cairn G obtained by Hensey et al. (2014). This model shows overall good agreement with the exception of the earliest (Cak18_RD1806) and the latest samples (CaK1_68). Removing these two 'outliers' the model supports one continuous phase of burial activity from 3454-3354 to 2894-2786 cal BC (at 95.4\% confidence).

Over this period (460-680 years) one can observe a number of changes in burial practice at the complex. The earliest four dates (including RD1086 which has been excluded from the model) are on cremated antler and, in fact, seven of the eight cremated antler samples are among the ten earliest dates from the complex. Therefore, it seems very likely that the deposition of cremated antlers represents the earliest activity at the complex (see below). Some of the earliest human remains within the Carrowkeel sequence are those samples that show evidence for post-mortem body processing in the form of cut-marks (CaK6_258, CaK15_63, CaK12_730, \& CaK14_1270). This suggests that dismemberment was practised during the primary use of the Carrowkeel tombs, between 3403-3026 and 3354-3014 cal BC, with no evidence for bones with cut-marks after 3000 cal BC. Cremated human remains occur broadly contemporaneously with the cut-marked ones, continuing from 3346-3097 to 3012-2887 cal BC. A plateau in the calibration curve at this point (Ashmore 2004; Schulting et al. 2017b) prevents further separation of these dates. While deposition of cremated remains may have continued during the 1st century of the 3rd millennium BC, after $c .3000$ cal $\mathrm{BC}$ unburnt bones and, in particular, skull fragments, appear to predominate. The last 20 samples in the sequence (with the exception of one canid tooth, CaK5_21) are all skull fragments and only two of them show evidence for cremation. It must be added as a caveat that, in order to facilitate isotope and aDNA analyses and to prevent duplicate samples (for details see Appendix S1), the sampling strategy for this project focused to a significant degree on unburnt cranial (mandible and temporal) bones. It therefore cannot be ruled out that interment of complete bodies was undertaken within the monuments and/or that there may be earlier cremated human remains in the assemblage than those identified here.

As an alternative to the above, a purely hypothetical model (ie, not based on archaeological constraints) can be proposed, which sees all the antler depositions - dating from 3641-3382 to 3366-3165 cal BC - preceding any of the human remains (Fig. 8; Table S2). This model - once the outlying earliest (also a cremated antler fragment) and latest dates in the sequence are again excluded - shows equally good agreement with the single sequence of depositions proposed above. While purely hypothetical, the model would present the cremated antlers at Carrowkeel as the earliest 
phase of activity. It also shows that the cut-marked bones date to the beginning of the sequence of human bone depositions, thus, like the first model, it suggests that the earliest identified human remains deposited at Carrowkeel were subject to dismemberment. There are various reasons, however, why we may not have human bone at dates as early as antler, including the collection strategy of the excavators and the sampling strategy of the current project. As noted above, the majority of the 29 dated human bone samples are on unburnt bone (with approximately $50 \%$ on human cranial elements), with only five samples (representing four individuals) of cremated human remains subjected to radiocarbon dating. Thus it cannot be excluded that further dating on cremated human bone may produce results as early as those already attained on cremated antler.

While it appears that depositions at Carrowkeel continued throughout most of the second half of the 4th and the first half of the $3 \mathrm{rd}$ millennia $\mathrm{BC}$, it is possible to suggest a rough sequence. It commences with the deposition of cremated antler remains (with or without human remains). Thereafter, a diverse range of burial practices can be observed, however, initially focused on the deposition of dismembered human body parts (until c. $3000 \mathrm{cal}$ BC) and of cremated human remains (until c. $2880 \mathrm{cal}$ BC). This appears to be broadly comparable, both chronologically and in terms of mixing of cremated and unburnt remains, with other elaborate Irish passage tombs (Cooney 2017). From the beginning of the 3rd millennium $\mathrm{BC}$ there seems to be a shift towards a focus on the deposition of unburnt skull bone, a practice that may present similarities to the evidence from the Mound of the Hostages, Tara, Co. Meath (O'Sullivan 2005; Bayliss \& O'Sullivan 2013). An unburnt human cranium, possibly placed in Cairn H, dating to 2834-2469 cal BC (91.5\% probability: 2636-2469 cal BC; UBA-30808), represents the latest sample identified as part of this project.

\section{[H2]Isotope analyses}

The principles of archaeological isotope analysis (of carbon, nitrogen, oxygen, and strontium) have seen considerable discussion in the recent archaeological literature (Bentley 2006; Montgomery 2010; Schulting 2011; Chenery et al. 2012; Evans et al. 2012; Klein 2013; Ditchfield 2014; Snoek et al. 2016; Neil et al. 2017). In brief and simplified terms, the ratio between the strontium isotopes ${ }^{87} \mathrm{Sr}$ and ${ }^{86} \mathrm{Sr}$ found in human and animal remains relates to the composition and, especially, the age, of the underlying bedrock geology and the resulting strontium composition in the biosphere (Bentley 2006; Montgomery 2010). The oxygen ratio (between ${ }^{16} \mathrm{O}$ and ${ }^{18} \mathrm{O}$ expressed as $\delta^{18} \mathrm{O}$ ) on the other hand relates to climate and, in particular, rainfall that is passed on into the cell metabolism through drinking water (Evans et al. 2010). The carbon 13 ratio (expressed as $\delta^{13} \mathrm{C}$ ) relates to diet. Measured on dental enamel carbonate (presented in Table 6 ), the $\delta^{13} \mathrm{C}_{\mathrm{C}}$ value reflects the blood bicarbonate reservoir and thus the total diet of an individual (Klein 2013; Ditchfield 2014) whereas when measured on bone collagen (presented in Table 3 ), $\delta^{13} \mathrm{C}$ is more sensitive towards dietary protein (Hedges 2003a; 2003b; Richards \& Schulting 2006). The nitrogen isotope ratio (expressed as $\delta^{15} \mathrm{~N}$ ), measured on collagen, is linked to the trophic level (position in the food chain) of the dietary proteins of foods consumed. As human dental enamel is cut off from circulation once the tooth is fully formed, all isotopic values measured on enamel represent the early years of an individual's life, while the teeth were forming. Therefore they are generally assumed to relate to the location where the individual was born and/or spent their childhood as well as the food and water they consumed during the early years of their lives (Bentley 2006; Montgomery 2010). In contrast, isotope measurements on bone collagen, which remains connected to circulation until the individual's death, represent their diet over a number of years prior to this point. However, the turnover rates vary between different bones, with a faster rate in less dense bones such as ribs compared to a slower remodelling rate of the long bones in the arms and legs (Sealy et al. 1995).

Tooth samples from 14 humans and one canid were analysed for carbon, oxygen, and strontium (Table 6). These remains, together with an additional ten unburnt human bone samples, were also (dated and) analysed for carbon and nitrogen isotopes on the collagen (Table 3). The carbon analysis of the 14 human enamel samples resulted in an average of $-16.9 \%$ ( \pm 0.6$)$ for $\delta^{13} \mathrm{C}_{\mathrm{C}}$ PDB (ranging from -17.6 to $-15.2 \%$ ). All the 14 values are consistent with a largely terrestrial-based diet, as is generally the case among Neolithic remains from north-west Europe (Richards \& Schulting 2006; Schulting et al. 2012; Ditchfield 2014; Schulting \& Boric 2017) and as could be expected from the inland position of Carrowkeel (located c. $20 \mathrm{~km}$ from the coast at Sligo Bay). This is further supported by the collagen $\delta^{13} \mathrm{C}$ values, which average at $-22.1( \pm 0.9)$ and range from -23.8 to $-21.4 \%$ and collagen $\delta^{15} \mathrm{~N}$ values, which average at $10.9( \pm 0.5)$, ranging from 9.9 to $11.7 \%$ o (Table 3 ). These values relate to all the 24 dated unburnt bone and tooth samples while, if taken only from the 14 mandibles used for strontium and oxygen analysis, the range for $\delta^{13} \mathrm{C}$ is narrower $\left(-22.6\right.$ to $-21.4 \%$ ) but is unchanged for $\delta^{15} \mathrm{~N}$. Carbon analysis of the canid tooth enamel (carbonate) returned a value of $-11.5 \%$ o $( \pm 0.6) \delta^{13} \mathrm{C}_{\mathrm{C}} \mathrm{PDB}$, which suggests the possibility of a significant marine contribution to the animal's diet (Laffoon et al. 2017). However, the stable carbon and nitrogen values ( -22.5 and 10.8\%o respectively) on dentine from the same tooth are broadly comparable with those of the human samples and thus do not support this conclusion (Table 3). Additional evidence suggests that this higher $\delta^{13} \mathrm{C}_{\mathrm{C}}$ value may relate to diagenetic alteration (see below).

Strontium analysis of the 14 human tooth enamel samples resulted in an average ratio of $0.7095( \pm 0.0008)$, ranging from 0.70863 to 0.71129 , while the canid tooth provided a ratio of 0.70860 . The four vegetation samples from the surrounding region range from 0.70973 to 0.71194 (Table 7). The two crown dentine samples taken from CaK8_10 and CaK8_11 measured 0.70889 and 0.70842 respectively. The dentine and canid enamel samples agree well with what could be expected for a Carboniferous environment (Evans et al. 2010; Ryan et al. 2018). The higher strontium concentrations of all three of these samples (Table 6) suggests that they have been subject to diagenesis since their deposition at Carrowkeel and are thus more reflective of the burial environment than of lifetime biosphere values of the respective individuals (Fig. 9; Montgomery et al. 2007). The plant samples, on the other hand, all have strontium ratios 
above 0.7097 (which is the upper limit for Carboniferous limestone suggested by Ryan et al. 2018) and thus highlight the presence of older geological formations in the wider region, in particular to the south of the monuments, where these samples were taken (Fig. 3).

All the enamel samples fall between the upper range marked by the plant remains and the lower limit of the dentine samples (Fig. 9). It is thus possible that all the sampled individuals came from within the north-western region of Ireland. However, this represents a relatively broad spectrum of strontium ratios and, while it is difficult to provide a more specific interpretation of the individual samples, it seems probable that a number of different geological backgrounds are represented. This in turn is in line with the relatively diverse geology of north-western Ireland. The majority of samples $(n=9)$ returned ratios between 0.7086 and 0.7097 , which can most probably be linked to an area of Carboniferous Limestone (Evans et al. 2010; Ryan et al. 2018), similar to the burial environment at Carrowkeel itself. The remaining five individuals with more radiogenic strontium ratios point to origins in areas of older geology, such as the Old Red Sandstone of the Curlew or the metamorphic (largely Granodiorite) geology of the Ox Mountains, $c .10 \mathrm{~km}$ south and $25 \mathrm{~km}$ north-west respectively (Fig. 3; Harney et al. 1996). In particular one sample (CaK8_09) seems considerably higher (2.36) than the other 13 and thus suggests a different source of biosphere strontium.

Oxygen analysis of the 14 human tooth enamel samples resulted in averages of: $-4.0 \%( \pm 0.5)$ for $\delta^{18} \mathrm{O}$ carbonate $\mathrm{PDB}$, ranging from -5.5 to $-3.4 \%$; and $26.8 \%$ o $( \pm 0.6)$ for $\delta^{18} \mathrm{O}$ SMOW, ranging from 25.2 to $27.4 \%$. The values for the canid tooth were $-5.8 \%$ o $( \pm 0.5) \delta^{18} \mathrm{O}$ PDB and $25.0 \%$ o $( \pm 0.6)$ SMOW, hence, like the $\delta^{13} \mathrm{C}_{\mathrm{C}}$, clearly below those measured on the human enamel samples. Given the discrepancies between the enamel carbonate and the collagen $\delta^{13} \mathrm{C}$ results they need to be treated with caution. Moreover, based on the substantially higher strontium concentration found in the canid tooth compared to the human dental enamel samples (see above and Table 6) it seems probable that diagenetic changes have acted upon the dental enamel of this tooth. While $\delta^{18} \mathrm{O}$ values measured on the carbonate cannot be directly related to rainwater values (Kohn 1996; Chenery et al. 2012), based on their oxygen isotope results, an origin within the north-west of Ireland seems probable for most of the samples. All but one of the 14 cluster between 26.2 and $27.4 \%$ o $\delta^{18} \mathrm{O}$ SMOW ( -4.6 to $-3.4 \%$ PDB) and are therefore in line with the expected range of $27.1 \pm 1 \%$ for central Ireland proposed by Cahill Wilson and Standish (2016; Darling et al. 2003; Diefendorf \& Patterson 2005). The remaining human enamel sample (CaK8_03) reporting a $\delta^{18} \mathrm{O}$ value of $25.2 \%$ o $( \pm 0.6) \delta^{18} \mathrm{O}$ SMOW $(-5.5 \pm 0.5 \%$ PDB $)$ is significantly below this range (2.86). Cahill Wilson and Standish characterise burials with $\delta^{18} \mathrm{O}_{\mathrm{C}}$ values below $26.0 \%$ SMOW ( $-4.7 \%$ PDB) as 'favouring an origin outside Ireland, for example in a cooler climate, at a higher latitude or altitude, or further from the Atlantic coast' $(2016,237)$. This sample is also one of the five with a strontium ratio above the likely range for Carboniferous limestone, although similar to the average of the vegetation samples.

Thus, as with the strontium ratios, the $\delta^{18} \mathrm{O}$ values suggest 13 of the 14 individuals from Carrowkeel fit well within what would be expected for the north-west of Ireland region but each of these analyses produced one outlier. Plotting the oxygen against the strontium results for the 12 individuals, excluding these two outliers (CaK8_03 \& 8_09), the values appear to be on a diagonal array (Fig. 10). This suggests a mixing line between two different sources (end users); one around $\delta^{18} \mathrm{O}=26.6 \%{ }^{87} \mathrm{Sr} /{ }^{86} \mathrm{Sr}=0.7086$ and the other around $\delta^{18} \mathrm{O}=27.5 \%{ }^{87} \mathrm{Sr} /{ }^{86} \mathrm{Sr}=0.7105$ (Montgomery et al. 2007). At the lower end, the strontium values are consistent with the Carboniferous environment dominating the immediate vicinity of the Bricklieve Mountains, but are also in line with rainwater which, in Atlantic north-west Europe, is similar to seawater (Evans et al. 2010; Montgomery 2010). The strontium ratios at the upper end appear to reflect the potentially older geology suggested by the plant remains which, for example, could relate to the Boyle, Moygara, and Keadew sandstone formations that make up the Curlew Mountains (Fig. 3; Harney et al. 1996).

Such a mixing line among these 12 individuals is associated with a Pearson correlation of $r=0.446$. While this is not significant $(\mathrm{p}=0.127$ ) in itself, this hypothesis can be further substantiated through assessing the correlation between $\delta^{13} \mathrm{C}_{\mathrm{C}}$ and ${ }^{87} \mathrm{Sr} /{ }^{86} \mathrm{Sr}$ among these same 12 individuals (Fig. 11). Here the Pearson correlation of $\mathrm{r}=-0.612$ is significant $(\mathrm{p}=0.026)$ and even if the two outliers are included the Pearson correlation of $\mathrm{r}=-0.573$ is still significant $(\mathrm{p}=0.04)$. Consequently, it seems plausible that the range of strontium ratios from Carrowkeel represents a spread of values between two sources of strontium that are reflected to different degrees in the diets of the 12 individuals. While this is difficult to substantiate further, at the lower end this could reflect the amount of animal produce (meat and dairy) people consumed which are low in strontium, and a more diverse and plant rich diet (higher in strontium) - partially sourced from an area of older geology - at the upper end. This appears to be further supported by Figure 9, which charts strontium concentrations against ratios, showing that the samples with lower strontium ratios also tend to have lower concentrations and vice versa. It is even more striking when comparing strontium and $\delta^{13} C_{C}$ values (Fig. 11), showing a clear (and significant) trend from lower $\delta^{13} \mathrm{C}$ values, among individuals with more radiogenic strontium ratios, towards higher $\delta^{13} \mathrm{C}$ values, among those with lower strontium ratios (closer to the values for Carboniferous limestone and/or rainwater).

\section{[H2]Ancient DNA analysis}

Six of the eight samples selected for aDNA analysis yielded usable levels of endogenous human DNA content (8.11$74.87 \%$ ). The two failed samples (CaK5_16 \& CaK17_375) both showed evidence for cremation, which is known to be detrimental to the survival of aDNA (Hansen et al. 2017). Of the six samples that were successfully shotgun sequenced to higher genomic coverage (Table 8), two were determined to be female and four to be male, which compares relatively well with the 9:4 ratio between males and females identified through osteological analysis. All six samples five of which came from the same monument (Cairn K) - exhibit genetic affinities similar to those of the Neolithic adult female (3343-3020 cal BC; 4465 \pm 38 BP; UB-7059) excavated at Ballynahatty, Co. Down (Cassidy et al. 2016). 
Preliminary results suggest their ancestry is derived predominantly from a source closely related to Neolithic Anatolians, as has been observed for their continental counterparts (Hofmanova et al. 2016), and expectedly they show high similarity to present-day Sardinians. The individuals also exhibit higher levels of allelic sharing with Early Neolithic Iberians relative to Early Neolithic central Europeans. This is consistent with genetic affinities observed for both the Ballynahatty genome and British Neolithic populations, which are argued to be the result of south-north migration and connectivity along the Atlantic seaboard (Cassidy et al. 2016; Olalde et al. 2018). European Mesolithic ancestry is also detectable in their genomes, at levels similar to the Ballynahatty individual (Cassidy et al. 2016).

Mitochondrial haplogroup analysis (Table 8) supports these precursory findings, with both haplogroups $\mathrm{H}$ and $\mathrm{X}$ previously identified as two of the dominant maternal lineages present in early farming populations across Europe. Haplogroup J1c has also been observed in these groups, with J1c3 seen in an Early Neolithic individual from Spain (Haak et al. 2015). The mtDNA haplogroup of CaK10_530, W5, appears to be much rarer, both in Neolithic and modern-day European populations (Olivieri et al. 2013) and requires further investigation.

It was possible to reconstruct approximately the pigmentation profile of the Carrowkeel population. The presence of the A111T haplotype at the SLC24A5 gene, associated with Western Eurasian light skin colour and fixed in modern European populations, was seen across samples. In addition, both ancestral and derived alleles were observed at the SNP rs16891982 (SLC45A2), the derived allele of which is associated with increased risk of melanoma, lighter skin, hair, and eye colour, and decreases in frequency on a north-south gradient in modern Europe (Norton et al. 2007). Estimation of hair and eye colour on a population level (Walsh et al. 2013), based on overall imputed allele frequencies, suggested the most common hair colour in the group was dark brown or black, with brown eye colour dominating, though variation associated with blue eyes was also observed.

Finally, assessment of potential kinship between pairs of samples, with robust inference of up to 4th-degree relatives (Lipatov et al. 2015), detected no very recent relatedness between any of the Carrowkeel individuals, suggesting they represent an outbreeding population. This is supported by preliminary runs of homozygosity analysis, based on imputed genotype data, which reveals no long segments ( $>8 \mathrm{Mb}$ ) of homozygosity present in any genome, suggesting none of these individuals is the result of a recent inbreeding event.

\section{[H1]DISCUSSION}

To make a meaningful investigation of human population dynamics based on the material from Carrowkeel possible it was essential to provide a chronological context for the human remains buried at the complex and link them, as best as possible, to the monuments from which they were excavated. The first stage in the process was connecting the material at the LCHES to the respective Carrowkeel tombs (Table 2; Meehan \& Hensey in press) and providing 38 new AMS radiocarbon determinations mainly on human, but also animal, remains (Table 3). Through these it has been possible to suggest two, somewhat different, chronological models for burial depositions at the complex. The first assumes that all the depositions - with the exception of an outlying early and late sample respectively - took place over one continuous phase (Fig. 7; Table S1). As the earliest dates in the sequence are on cremated antler, an alternative hypothetical model might suggest that the cremated antler remains represent an initial phase predating the (to date identified) human bone remains at the complex (Fig. 8; Table S2). The fact that the earliest dates at Carrowkeel come from cremated antler, whether this constitutes a distinct depositional phase or not, is intriguing and requires further investigation. In particular, it needs to be established whether this could reflect specific burial practices at the tombs (Worley \& Serjeantson 2014), or if this apparent phase of discrete deposition of antler without similarly dated human bone may be an artefact of the collection strategy of the 1911 excavations, or of the necessity to primarily sample unburnt bone in this project. The records of Macalister et al. (1912) suggest that antler was found mixed with human bone.

More generally, cremated antler, often in the form of pins, is a relatively common and significant find at Irish passage tombs, suggesting that red deer held important symbolic significance for Neolithic communities. The deposition of antler pins can be directly related to human burials (Herity 1974; Eogan 1986; Cooney \& Grogan 1994; O'Sullivan 2005; Bergh \& Hensey 2013) and several such pins have been identified at Carrowkeel (Macalister et al. 1912). A recent dating project of the Carrowmore passage tomb complex (c. $22 \mathrm{~km}$ north of Carrowkeel) was focused on the dating of cremated antler pins (Bergh \& Hensey 2013). While most of the antler fragments from Carrowkeel are too small to ascertain their role definitively, it is probable that at least some of them once formed parts of pins (Fig. 5) and their dates are virtually synchronous with the date range that seemed to represent the most intensive phase of depositions at Carrowmore (c. 3600-3200 cal BC). Another potentially significant discovery is the identification of possible red deer bone from Cairn K. If this can be further substantiated, it would support the presence of red deer in Neolithic Ireland, rather than the antlers being imported, thus contributing to a long-running debate regarding this question (Woodman \& McCarthy 2003; Carden et al. 2012).

The earliest identified human remains from Carrowkeel - though near contemporaneous with cremated human bone samples - are unburnt bones that show evidence for dismemberment. There are no samples with cut-marks postdating $3000 \mathrm{cal}$ BC and no cremated bone after $2880 \mathrm{cal}$ BC. Consequently, these remains are broadly in line with the recognised Irish Middle Neolithic II (Whitehouse et al. 2014; McLaughlin et al. 2016) and correspond to the period (3300-3000/2900 cal BC) traditionally considered the main phase for 'developed Irish passage tombs' (Schulting et al. $2017 \mathrm{~b}, 14)$. From around $3000 \mathrm{cal}$ BC, unburnt human cranial bone fragments dominate the assemblage. The dates for these remains are broadly in line with the onset of the recognised Irish Late Neolithic (Cooney 2000; Cooney et al. 2011; Whitehouse et al. 2014; McLaughlin et al. 2016). Hence the continued period of depositions after c. 2900 BC, focusing on unburnt crania, marks Carrowkeel out as different from other passage tomb complexes, though the focus on 
crania shows some potential similarities to the Mound of the Hostages (O’Sullivan 2005; Bayliss \& O'Sullivan 2013). The relatively limited amount of Bronze Age finds notwithstanding, they seem to mark the end of prehistoric funerary activity at the complex.

A number of recent high-resolution studies combining palaeolimnological investigation with pollen and geochemical analyses of sediments in two nearby lakes - Templevanny Lough, $c .1 \mathrm{~km}$ south-west, and Loughmeenaghan, $c .3 \mathrm{~km}$ north-west of Carrowkeel - have identified evidence for Neolithic pastoral farming activity in the catchment areas of both lakes in several key phases (Stolze et al. 2012; 2013; Taylor et al. 2016). The studies reveal that the most intensive evidence for (pastoral) farming dates to the Early Neolithic between $c .3750$ and $3500 \mathrm{BC}$ and wanes after this date. This pattern of low levels of farming activity, accompanied by partial woodland recovery, persists throughout both the Middle and Late Neolithic periods, albeit with a brief period of increased small-scale pastoral farming identified at Templevanny c. 2980-2910 BC (Taylor et al. 2016, 9). Stolze and colleagues (2012; 2013) suggest that the changes in agricultural practice may relate to climatic oscillations. At Templevanny they detected a period of climatic downturn and increased rainfall c. 3600-3290 BC, leading to 'an almost complete woodland recovery between $c .3080$ and 3070 BC' (Stolze et al. 2013, 148). While at Loughmeenaghan they date the climatic downturn and recurring periods of increased precipitation to 3520-3170 BC (Stolze et al. 2012, 400).

The earliest depositions at Carrowkeel, commencing between c. 3600 and 3350 cal BC, appear to coincide with the onset of these worsening weather conditions and a near-cessation of farming activity in the area. Moreover, the brief period of increased pastoral farming in the 30th century $\mathrm{BC}$ seems to correspond with the change in burial tradition from a diverse range of practices, including both dismemberment and cremation, to a focus on the deposition of unburnt cranial bones. Thus the evidence from the complex may support the suggestion that changing land-use practices (Taylor et al. 2016), declining human activity, and climatic deterioration may have been factors in the expansion of the Irish passage tomb tradition (see Hensey 2015 for discussion). This mirrors significant developments in monument construction elsewhere in Neolithic north-west Europe (Gronenborn 2009; Lechterbeck et al. 2014; Downey et al. 2014; 2016).

The opportunity to reassess the Carrowkeel remains has provided several additional important insights. Arguably the most significant finding has been the identification of a series of cut-marks on 12 human bones that indicate the post-mortem dismemberment of the dead as part of the burial rite. In their analysis of the assemblage from Coldrum Long Barrow, Kent, England, Wysocki and colleagues suggested that dismemberment of (unburnt) human corpses may point to a variety of meanings, associated with the availability of portable bone and possibly practices such as '[n]ecrophagy, shamanism [or] witchcraft' $(2013,69)$. Cremation, it could be contended, is a very different process carrying different ritual meanings (Larsson \& Stutz 2014; Williams 2014). At Carrowkeel, however, the dismemberment of unburnt bodies was contemporaneous with the use of cremation. This combination of practices may have represented rites of passage to 'aid the deceased ... in the transition to a state of post-mortem existence' (Geber et al. 2017, 44). Cooney advocates that cremation and unburnt burial 'should not be seen as opposed rites' (2017, 294). Indeed, the practice of skilled dismemberment on corpses may be relevant to Cooney's $(2017,395,400)$ proposal that at Knowth, cremated and unburnt bone may, in some cases, derive from a single individual. Notably, A. Macalister appears to have considered the 'apparent contemporaneity' of cremated and unburnt bone in his analysis of the remains from the 1911 excavations. In one of his notes, preserved (in box CaK 2) at the LCHES, he observed that burnt and unburnt bone were often encountered mixed together.

More broadly, the significant proportion of unburnt human bone (c. $45 \%$ based on MNI) within the Carrowkeel assemblage, runs contrary to the general view of cremation being the dominant funerary rite at Irish passage tombs (Herity 1974; Cooney \& Grogan 1994; Cooney 2000; Buckley et al. 2017). It is, however, unclear whether this means that the funerary practices at Carrowkeel were significantly different from other Irish passage tombs (Cooney 2017) or whether the higher proportion of unburnt material is largely the result of collection bias during the 1911 excavations and/or favourable preservation of unburnt bone in the karstic environs of Carrowkeel.

Contrastingly, in line with the general view of passage tombs, with a minimum number of 29 individuals (or 40 if counting cremated and unburnt material separately) from seven tombs - in interments that span a period of between five and 11 centuries - it appears that Neolithic communities were selective in choosing who to bury at the complex. This corresponds to a wider trend among megalithic burials in Ireland (Cooney 2017) and north-western Europe more generally (Midgley 2008; Laporte \& Scarre 2016) and raises the question on what basis people were selected for burial within megalithic tombs. From the evidence at Carrowkeel, it is unlikely that selection was based on sex or age, as the assemblage represents a broad demographic range, with all age groups from infants to older adults and both males and females (albeit at a skewed ratio) being accounted for. The substantial presence (c. 35\%) of non-adults in the assemblage, points to all age groups receiving 'equal treatment' in death and suggests that children and adolescents were valued members of their communities (Waterman \& Thomas 2011, 178). The fact that aDNA analysis found no evidence for direct kinship among the individuals whose bones were deposited in the tombs - even though five of the six successful samples came from the same tomb - highlights that family groupings were unlikely to have been the basis of selection for placement in the tombs. As an alternative explanation for the low number of identifiable individuals at Irish passage tombs, it could be proposed that tombs may have been regularly cleared of bone (for deposition elsewhere) with only a small amount of each generation staying behind (Scarre 2011; 185-8; Cooney 2018; 406-7; Schulting et al. 2018, 378).

On a population level, aDNA evidence revealed a genetic profile in keeping with other Neolithic population samples from north-west Europe (Cassidy et al. 2016; Olalde et al. 2018), with ultimate origins in western Anatolia but 
also more immediate affinities with remains from the Iberian Neolithic. This seems to reflect the importance of Atlantic seaways in the spread of agriculture and megalithic burial traditions to north-west Europe (Sheridan 2003; 2010).

Isotope evidence suggests that the majority of individuals buried at the Carrowkeel complex are most likely local to Ireland's north-western region. However, two samples differ markedly in their strontium and oxygen ratios respectively, which may point to these individuals having originated from outside the region. Among the remaining 12 individuals a linear relationship between strontium and both carbon and oxygen ratios as well as strontium concentrations suggests that the people buried at Carrowkeel may have sourced their food from two different regions within the north-west of Ireland, highlighting the possibility that this could point to social differentiation, as reflected in their diets, among those deposited at the tombs.

\section{[H2]Conclusions}

The multidisciplinary approach employed in the analysis of the burial population at Carrowkeel has served to enhance our current understanding of life and death during an important phase of the Irish Neolithic.

First, the results emphasise the highly complex and varied character of mortuary practices in the Irish passage tomb tradition, which evolved over a sustained period. The study identified the practice of dismembering human remains and showed this to have been conducted contemporaneously with that of cremation. In quantifying the remains it could be established that near equal proportions of the assemblage are represented in the cremated and unburnt material; that male and female adults as well as non-adults are accounted for; and that animals, both wild and domesticated, played important roles in people's lives and accompanied them in death.

Secondly, through 38 new radiocarbon determinations, the project has provided a chronology for the complex suggesting that its initial use occurs around the middle of the 4th millennium BC. This succeeds relatively closely the earliest phases at Carrowmore (Bergh \& Hensey 2013) and pre-dates most other passage tomb evidence from Ireland, such as the Boyne Valley tombs (Cooney et al. 2011; Bayliss \& O'Sullivan 2013; Schulting et al. 2017a). The extended duration of usage of Carrowkeel for the deposition of bone is notable, covering more than half a millennium. The model also indicates a number of changes in burial practice over time, potentially in line with apparent periods of climatic oscillation and changes in Neolithic farming practice, identified more broadly across Ireland (Whitehouse et al. 2014; McLaughlin et al. 2016) and north-west Europe (Whittle et al. 2011; Lechterbeck et al. 2014; Downey et al. 2014; 2016).

Thirdly, a combination of multi-isotope analysis and aDNA sequencing has demonstrated that a relatively diverse population accessed the monuments for ritual and burial purposes over several centuries. They placed within the chambers of Carrowkeel multiple individuals whose deep ancestry was in Anatolia, but who had grown up and lived their lives in the environs of Lough Arrow, the Bricklieve Mountains or regions nearby, as well as a small number of individuals possibly from outside the region. Finally, the isotope research also hints at the possibility that the majority of the individuals identified at Carrowkeel sourced their food from two different areas within the region. This could reflect a level of social differentiation within the community, expressed through access to different food sources, or the presence of distinct populations, originating from several areas within the northwest of Ireland region, among the deposited remains.

[9P]Acknowledgements: We would like to acknowledge the kind support from the Leverhulme Centre for Human Evolutionary Studies (LCHES), Cambridge and especially Marta Mirazón Lahr and Maggie Belatti, for granting and facilitating access to the Carrowkeel collection. We also wish to thank the Antiquities Division of the National Museum of Ireland for providing access to the material from Carrowkeel in that collection and the Geological Survey of Ireland for providing vegetation samples from the TELLUS border project. AMS radiocarbon dating was supported through grants from the Prehistoric Society (SUERC), the National Radiocarbon Facility (Oxford), and the Royal Irish Academy $\left({ }^{14}\right.$ Chrono Centre). We thus wish to thank all these agencies for their very kind support. Ancient DNA analysis carried out by Lara M. Cassidy was funded by the Irish Research Council Government of Ireland Scholarship Scheme (GOIPG/2013/1219). Additional research support was provided by the Bristol Isotope Group (University of Bristol), the Department of Earth Sciences (Durham University), the British Geological Survey, UCL Earth Sciences as well as the Human Population Genetics Laboratory (Trinity College Dublin). In this context we wish to especially acknowledge the support from Alex Bentley, Colin MacPherson, Daniel Bradley, and John McArthur. We also wish to thank Alison Sheridan for having drawn attention to the existence of the Carrowkeel material at Cambridge; Kevan Edinborough for his advice on chronological modelling; Kerri Cleary for helping with access to materials; Charlotte King and Vesna Lukic for commenting on various drafts of this paper; and the three anonymous reviewers, as well as Julie Gardiner for her editorial advice. Finally, the research formed part of a Marie Skłodowska Curie Research Fellowship (Thomas Kador), funded under the seventh Framework for European Research Innovation Funding (FP7) and we thus wish to acknowledge the support received from the European Research Executive Agency.

\section{[H1]BIBLIOGRAPHY}

[BIBL]Ashmore, P.J. 2004. Absolute chronology. In I.A.G. Shepherd \& G.J. Barclay (eds), Scotland in Ancient Europe: The Neolithic and Early Bronze Age of Scotland in their European context, 125-36. Edinburgh: Society of Antiquaries of Scotland

Bayliss, A. \& O'Sullivan, M. 2013. Interpreting chronologies for the Mound of the Hostages, Tara and its contemporary contexts in Neolithic and Bronze Age Ireland. In M. O’Sullivan, C. Scarre \& M. Doyle (eds), Tara - From the Past to the Future. Towards a New Research Agenda, 26-104. Dublin: Wordwell

Bentley, R.A. 2006. Strontium isotopes from the earth to the archaeological skeleton: A review. Journal of Archaeological Method \& Theory 13, 135-87 
Bergh, S. 1995. Landscape of the Monuments: A study of the passage tombs in the Cúil Irra Region, Co Sligo, Ireland. Stockholm: Riksantikvarieämbetet

Bergh, S. \& Hensey, R. 2013. Unpicking the chronology of Carrowmore. Oxford Journal of Archaeology 32(4), 343-66

Bradley, R. 1998. The Significance of Monuments: On the shaping of human experience in Neolithic and Bronze Age Europe. London: Routledge

Brickley, M.B. \& McKinley, J.I. (eds). 2004. Guidelines to the Standards for Recording Human Remains. Reading: British Association for Biological Anthropology and Osteoarchaeology/Institute for Field Archaeologists Paper 7

Brindley, A. 2007. The Dating of Food Vessels and Urns in Ireland. Galway: National University of Ireland, Galway

Buckley, L., Power C., O’Sullivan, R. \& Thakore, H. 2017. The human remains. In Eogan \& Cleary (eds) 2017, 277-329

Buikstra, J.E. \& Ubelaker, D.H. 1994. Standards for Data Collection from Human Skeletal Remains. Fayetteville: Arkansas Archaeological Survey Research Series 44

Burenhult, G. 1998. The Swedish Excavations at Carrowmore, Co. Sligo, Ireland. Campaign Season 1998. Excavation Report: Tomb No. 51 (Listoghil) (SMR Number SL014-20922). Unpublished report. Stockholm: Stockholm University Department of Archaeology

Burenhult, G. 2003. The chronology of Carrowmore. In G. Burenhult (ed.), Stones and Bones: Formal disposal of the dead in Atlantic Europe during the Mesolithic-Neolithic interface 6000-3000 BC, 66-9. Oxford: British Archaeological Report S1201

Cahill, M. \& Sikora, M. 2011. Breaking Ground, Finding Graves - Reports on the Excavations of Burials by the National Museum of Ireland, 1927-2006. Dublin: Wordwell

Cahill Wilson, J. \& Standish, C. 2016. Mobility and migration in late Iron Age and early medieval Ireland. Journal of Archaeological Science 6, 230-41

Carden, R.F., McDevitt, A.D., Zachos, F.E., Woodman, P.C., Rose, H., Monaghan, N.T., O’Toole, P., Campana, M.G., Bradley, D.G. \& Edwards, C.J. 2012. Phylogeographic, ancient DNA, fossil and morphometric analyses reveal ancient and modern introductions of a large mammal: The complex case of red deer (Cervus elaphus) in Ireland. Quaternary Science Review $42,74-84$

Cassidy, L.M., Martiniano, R., Murphy, E., Teasdale, M.D., Mallory, J., Hartwell, B. \& Bradley, D.G. 2016. Neolithic and Bronze Age migration to Ireland and establishment of the insular Atlantic genome. Proceedings of the National Academy of Sciences of the United States of America 113(2), 368-73

Chenery, C.A., Pashley, V., Lamb, A.L., Sloane, H.J. \& Evans, J.A. 2012. The oxygen isotope relationship between the phosphate and structural carbonate fractions of human bioapatite. Rapid Communications in Mass Spectrometry 26, 309-19

Cooney, G. 2000. Landscapes of Neolithic Ireland. London: Routledge

Cooney, G. 2014. The role of cremation in mortuary practice in the Irish Neolithic. In Kuijt et al. (eds) 2014, 189-206

Cooney, G. 2016. Pathways to ancestral worlds: Mortuary practice in the Irish Neolithic. In K. Brophy (ed.), The Neolithic of Mainland Scotland, 79-94. Edinburgh: Edinburgh University Press

Cooney, G. 2017. The Knowth mortuary practises in context. In Eogan \& Cleary (eds) 2017, 387-410

Cooney, G. \& Grogan, E. 1994. Irish Prehistory: A social perspective. Dublin: Wordwell

Cooney, G., Bayliss, A., Healy, F., Whittle, A., Danaher, E., Cagney, L., Mallory, J.P., Smyth, J., Kador, T. \& O’Sullivan, M. 2011. Ireland. In Whittle et al. (eds) 2011, 562-669

Darling, W.G., Bath, A.H. \& Talbot, J.C. 2003. The O \& H stable isotopic composition of freshwaters in the British Isles. Surface waters and groundwater. Hydrological Earth Systems Science 7, 183-95

Diefendorf, A.F. \& Patterson, W.P. 2005. Survey of stable isotopes values in Irish surface waters. Journal of Paleolimnology 34, 257-69

Ditchfield, P. 2014. Stable isotope analysis. In A. Lynch (ed.), Poulnabrone, Co. Clare. Excavation of an Early Neolithic Portal Tomb, 86-92. Dublin: Department of Arts, Heritage and the Gaeltacht Archaeological Monograph Series 9

Downey, S.S., Bocaege, E., Kerig, T., Edinborough, K. \& Shennan, S. 2014. The Neolithic demographic transition in Europe: Correlation with Juvenility Index supports interpretation of the Summed Calibrated Radiocarbon Date Probability Distribution (SCDPD) as a valid demographic proxy. PLOS ONE 9(8), e105730

Downey, S.S., Haas, W.R. \& Shennan, S.J. 2016. European Neolithic societies showed early warning signals of population collapse. Proceedings of the National Academy of Science of the USA 113(35), 9751-56

Egan, U., Byrne, E., Sleeman, M., Ronan, S. \& Murphy, C. 2005. Archaeological Inventory of County Sligo Vol. 1: Sligo South. Dublin: Stationary Office

English Heritage 2014. Animal Bones and Archaeology. Guidelines for Best Practice. Portsmouth: English Heritage

Eogan, G. 1986. Knowth and the Passage-Tombs of Ireland. London: Thames \& Hudson

Eogan, G. \& Cleary, K. (eds). 2017. Excavations at Knowth 6. The passage tomb archaeology of the great mound at Knowth. Dublin: Royal Irish Academy

Evans, J.A., Chenery, C.A. \& Montgomery, J. 2012. A summary of strontium and oxygen isotope variation in archaeological human tooth enamel excavated from Britain. Journal of Analytical Atomic Spectrometry 27, 754-64

Evans, J.A., Montgomery, J., Wildman, G. \& Boulton, N. 2010. Spatial variations in biosphere 87Sr/86Sr in Britain. Journal of the Geological Society 167, 1-4

Fleming, A. 1973. Tombs for the living. Man 8, 177-93

Gallucci, M., Ongaro, F., Amici, G.P. \& Regini, C. 2009. Frailty, disability and survival in the elderly over the age of seventy: Evidence from The Treviso Longeva (TRELONG) Study. Archives of Gerontology and Geriatrics 48(3), 281-83

Geber, J., Hensey, R., Meehan, P., Moore, S. \& Kador, T. 2016. Reassessing the age, sex and metric variation of commingled human remains from a 1911 excavation of a Neolithic passage tomb complex in north-west Ireland. International Journal of Osteoarchaeology 27(2), 131-42

Geber, J., Hensey, R., Meehan, P., Moore, S. \& Kador, T. 2017. Facilitating transitions: Postmortem processing of the dead at the Carrowkeel Passage Tomb Complex, Ireland (3500-3000 cal B.C.). Bioarchaeology International 1(1-2), 35-51

Gronenborn, D. 2009. Climate fluctuations and trajectories to complexity in the Neolithic: Towards a theory. Documenta Praehistorica 36, 97-110 
Haak, W., Lazaridis, I., Patterson, N., Rohland, N., Mallick, S., Llamas, B., Brandt, G., Nordenfelt, S., Harney, E., Stewardson, K. \& $\mathrm{Fu}, \mathrm{Q}$. 2015. Massive migration from the steppe was a source for Indo-European languages in Europe. Nature 522, 207-11

Hansen, H.B., Damgaard, P.B., Margaryan, A., Stenderup, J., Lynnerup, N., Willerslev, E. \& Allentoft, M.E. 2017. Comparing ancient DNA preservation in petrous bone and tooth cementum. PLoS One 12(1), p.e0170940

Harney, S., Long, C. \& MacDermott, C.V. 1996. Geology of Sligo-Leitrim. Dublin: Geological Survey of Ireland

Hedges, R.E.M. 2003a. Isotopes and red herrings: Comments on Milner et al. and Liden et al. Antiquity 78, 34-47

Hedges, R.E.M. 2003b. On bone collagen - apatite-carbonate isotopic relationships. International Journal of Osteoarchaeology 13(1-2), 66-79

Hensey, R. 2015. First Light: The origins of Newgrange. Oxford: Oxbow Insights in Archaeology 1

Hensey, R., Meehan, P., Dowd, M. \& Moore, S. 2014. A century of archaeology - historical excavation and modern research at the Carrowkeel passage tombs, County Sligo. Proceedings of the Royal Irish Academy 114C, 57-87

Herity, M. 1974. Irish Passage Graves: Neolithic tomb builders in Ireland and Britain 2500 BC. Dublin: Irish University Press

Hofmanová, Z., Kreutzer, S., Hellenthal, G., Sell, C., Diekmann, Y., Díez-del-Molino, D., van Dorp, L., López, S., Kousathanas, A., Link, V. \& Kirsanow, K. 2016. Early farmers from across Europe directly descended from Neolithic Aegeans. Proceedings of the National Academy of Sciences 113(25), 6886-91

Holland, C.H. 2003. The Geology of Ireland. Edinburgh: Dunedin Academic Press

Kador, T., Fibiger, L., Cooney, G. \& Fullagar, P. 2015a. Movement and diet in early Irish prehistory: First evidence from multiisotope analysis. Journal of Irish Archaeology 23, 83-96

Kador, T., Geber, J., Hensey, R., Meehan, P. \& Moore, S. 2015b. New dates from Carrowkeel. PAST 79, 12-14

Klein, R.G. 2013. Stable carbon isotopes and human evolution. Proceedings of the National Academy of Science of the USA 110(26), 10470-72

Kohn, M.J. 1996. A predictive model for animal 180: Accounting for diet and physiological adaptation. Geochimica et Cosmochimica Acta 60, 4811-29

Kuijt, I. Quinn, C. \& Cooney G. (eds). 2014. Transformation by Fire: The archaeology of cremation in cultural context. Tucson, AZ: University of Arizona Press

Larsson, Å. \& Stutz, L. 2014. Reconcilable differences: Cremation, fragmentation, and inhumation in Mesolithic and Neolithic Sweden. In Kuijt et al. (eds) 2014, 47-66

Laffoon, J.E., Hoogland, M.L., Davies, G.R. \& Hofman, C.L. 2017. A Multi-isotope investigation of human and dog mobility and diet in the pre-colonial Antilles. Environmental Archaeology 23(1), 1-17

Laporte, L. \& Scarre, C. (eds). 2016. The Megalithic Architectures of Europe. Oxford: Oxbow Books

Lechterbeck, J., Edinborough, K., Kerig, T., Fyfe, R., Roberts, N. \& Shennan, S. 2014. Is Neolithic land use correlated with demography? An evaluation of pollen-derived land cover and radiocarbon-inferred demographic change from Central Europe. Holocene 24(10), 1297-307

Lipatov, M., Sanjeev, K., Patro, R. \& Veeramah, K. 2015. Maximum likelihood estimation of biological relatedness from low coverage sequencing data. BioRixiv, https://doi.org/10.1101/023374

Lucas, A.T. 1963. National Museum of Ireland archaeological acquisitions in the year 1961. Journal of the Royal Society of Antiquaries of Ireland 93(2), 115-33

Macalister, R.A.S., Armstrong, E.C.R. \& Praeger, R.L. 1912. Report on the exploration of Bronze-Age carns on Carrowkeel Mountain, Co. Sligo. Proceedings of the Royal Irish Academy 29C, 311-47

MacHugh, D.E., Edwards, C.J., Bailey, J.F., Bancroft, D.R. \& Bradley, D.G. 2000. The extraction and analysis of ancient DNA from bone and teeth: A survey of current methodologies. Ancient Biomolecules 3(2), 81-103

McAteer, C. \& Parkes, M. 2004. The Geological Heritage of Sligo. An Audit of County Geological Sites in Sligo. Unpublished Report, Geological Survey of Ireland

McAulay, I.R. \& Watts, W.A. 1961. Dublin radiocarbon dates I. Radiocarbon 3, 26-38

McLaughlin, T.R., Whitehouse, N.J., Schulting, R.J., McClatchie, M., Barratt, P. \& Bogaard, A. 2016. The changing face of Neolithic and Bronze Age Ireland: A big data approach to the settlement and burial records. Journal of World Prehistory 29(2), 117-53

Meehan, P. \& Hensey, R. in press. Carrowkeel to Cambridge: Resolving the origins of a Neolithic bone assemblage. Proceedings of the Royal Irish Academy $118 \mathrm{c}$

Meyer, M. \& Kircher, M. 2010. Illumina sequencing library preparation for highly multiplexed target capture and sequencing. Cold Spring Harbor Protocols 6, DOI: 10.1101/pdb.prot5448

Midgley, M. 2008. The Megaliths of Northern Europe. London: Routledge

Montgomery, J. 2010. Passports from the past: Investigating human dispersals using strontium isotope analysis of tooth enamel. Annals of Human Biology 37, 325-46

Montgomery, J., Evans, J.E. \& Cooper, R.E. 2007. Resolving archaeological populations with Sr-isotope mixing models. Applied Geochemistry 22, 1502-14

Murphy, E. 2003. Funerary processing of the dead in prehistoric Ireland. Archaeology Ireland 17(2), 13-15

Murphy, E., O’Donnabhain, B., Welsh, H. \& McGranaghan, C. 2010. INSTAR - The people of prehistoric Ireland: Phase 1. Archaeology Ireland 24(1), 23-25

Neil, S., Montgomery, J., Evans, J., Cook, G.T. \& Scarre, C. 2017. Land use and mobility during the Neolithic in Wales explored using isotope analysis of tooth enamel. American Journal of Physical Anthropology 164(2), 371-93

Norton, H.L., Kittles, R.A., Parra, E., McKeigue, P., Mao, X., Cheng, K., Canfield, V.A., Bradley, D.G., McEvoy, B. \& Shriver, M.D. 2007. Genetic evidence for the convergent evolution of light skin in Europeans and East Asians. Molecular Biology and Evolution, 24(3), 710-22

O’Donnabhain, B. \& Tesorieri, M. 2014. Bioarchaeology. In A. Lynch (ed.), Poulnabrone, Co. Clare. Excavation of an Early Neolithic portal tomb, 61-86. Dublin: Department of Arts, Heritage and the Gaeltacht Archaeological Monograph Series 9

O'Kelly, M.J. 1989. Early Ireland. Cambridge: Cambridge University Press

Olalde, I., Brace, S., Allentoft, M.E., Armit, I., Kristiansen, K., Booth, T., Rohland, N., Mallick, S., Szécsényi-Nagy, A., Mittnik, A. \& Altena, E. 2018. The Beaker phenomenon and the genomic transformation of northwest Europe. Nature 555(7695), 1908 
Olivieri, A., Pala, M., Gandini, F., Kashani, B.H., Perego, U.A., Woodward, S.R., Grugni, V., Battaglia, V., Semino, O., Achilli, A., Richards, M.B. \& Torroni, A. 2013. Mitogenomes from two uncommon haplogroups mark Late Glacial/Postglacial expansions from the Near East and Neolithic dispersals within Europe. PLOS One 8(7), e70492

O'Sullivan, M. 2005. Duma na nGiall, Tara, the Mound of the Hostages. Bray: Wordwell

Richards, M.P. \& Schulting, R.J. 2006. Touch not the fish: The Mesolithic-Neolithic change of diet and its significance. Antiquity $80,444-56$

Roberts, C. \& Cox, M. 2003. Health and Disease in Britain: From prehistory to the present day. Stroud: Sutton

Ryan, S.E., Snoeck, C., Crowley, Q.G. \& Babechuk, M. $2018 .{ }^{87} \mathrm{Sr} /{ }^{86} \mathrm{Sr}$ and trace element mapping of geosphere-hydrospherebiosphere interactions: A case study in Ireland. Applied Geochemistry 92, 209-24

Rynne, E. 1969. Cist-burial in a cairn at Treanmacmurtagh, Co. Sligo. Journal of the Royal Society of Antiquaries of Ireland 99(2), $145-50$

Scarre, C. 2011. Landscapes of Neolithic Brittany. Oxford: Oxford University Press

Schmid, E. 1972. Atlas of Animal Bones: For prehistorians, archaeologists and quaternary geologists. Amsterdam: Elsevier

Schulting, R.J. 2011. Mesolithic-Neolithic transitions: An isotopic tour through Europe. In R. Pinhasi \& J. Stock (eds), The Bioarchaeology of the Transition to Agriculture, 17-41. New York, NY: Wiley-Liss

Schulting, R.J. \& Boric, D. 2017. A tale of two processes of Neolithisation: South-east Europe and Britain/Ireland. In P. Bickle, V. Cummings, D. Hofmann \& J. Pollard (eds), The Neolithic of Europe: Papers in Honour of Alasdair Whittle, 82-106. Oxford: Oxbow Books

Schulting, R.J., Bronk Ramsey, C., Reimer, P., Eogan, G. Cleary, K., Cooney, G. \& Sheridan, A. 2017a. Dating Neolithic human remains at Knowth. In Eogan \& Cleary (eds) 2017, 331-85

Schulting, R.J., McClatchie, M., Sheridan, A., McLaughlin, R., Barratt, P. \& Whitehouse, N.J. 2017b. Radiocarbon dating of a multiphase passage tomb on Baltinglass Hill, Co. Wicklow, Ireland. Proceedings of the Prehistoric Society 83, 305-23

Schulting, R.J., Murphy, E., Jones, C. \& Warren, G. 2012. New dates from the north, and a proposed chronology for Irish court tombs. Proceedings of the Royal Irish Academy 112C, 1-60

Sealy, J., Armstrong, R. \& Schrire, C. 1995. Beyond lifetime averages: Tracing life histories through isotopic analysis of different calcified tissues from archaeological human skeletons. Antiquity 69, 290-300

Serjeantson. D. 2011. Review of Animal Remains from the Neolithic and Early Bronze Age Southern Britain. Portsmouth: English Heritage.

Shee Twohig, E. 1990. Irish Megalithic Tombs. London: Shire

Sheridan, J.A. 2003. Ireland's earliest passage tombs: A French connection? In G. Burenhult \& S. Westergaard (eds), Stone and Bones: Formal disposal of the dead in Atlantic Europe during the Mesolithic-Neolithic interface 6000-3000 BC, 9-26. Oxford: British Archaeological Report S1201

Sheridan, J.A. 2010. The Neolithization of Britain and Ireland: The big picture. In B. Finlayson \& G. Warren (eds), Landscapes in Transition, 89-105. Oxford: Oxbow Books

Snoeck, C., Pouncett, J., Ramsey, G., Meighan, I., Mattielli, N., Goderis, S. \& Schulting, R. 2016. Mobility during the Neolithic and Bronze Age in Northern Ireland explored using strontium isotope analysis of cremated human bone. American Journal of Physical Anthropology 160, 397-413

Stolze, S., Dörfler, W., Monecke, T. \& Nelle, O. 2012. Evidence for climatic variability and its impact on human development during the Neolithic from Loughmeenaghan, County Sligo, Ireland. Journal of Quaternary Science 27, 393-403

Stolze, S., Muscheler, R., Dörfler, W. \& Nelle, O. 2013. Solar influence on climate variability and human development during the Neolithic: Evidence from a high-resolution multi-proxy record from Templevanny Lough, County Sligo, Ireland. Quaternary Science Review 67, 138-59

Taylor, E. \& Laurencin, C.T. 2009. Etiology, diagnosis, and nonoperative treatment of the arthritic shoulder. In D.M. Dines, C.T. Laurencin \& G.R. Williams Jr (eds), Arthritis \& Arthroplasty: The shoulder, 3-11. Philadelphia, PA: Saunders

Taylor, K.J., Stolze, S., Beilman, D. \& Potito, P. 2016. Response of chironomids to Neolithic land-use change in north-west Ireland. Holocene 27(6), 1-11

Triantaphyllou, S. Kador, T. \& Nikitae, E. 2015. Exploring mobility patterns and biological affinities in the southern Aegean: First insights from Early Bronze Age eastern Crete, Greece. Annual of the British School at Athens 110, 1-23

Waddell, J. 1990. The Bronze Age Burials of Ireland. Galway: Galway University Press

Waddell, J. 1998. The Prehistoric Archaeology of Ireland. Galway: Galway University Press

Walsh, S., Liu, F., Wollstein, A. Kovatsi, L., Ralf., A., Kosiniak-Kamysz, A., Branicki, W. \& Kayser, M. 2013. The HIrisPlex system for simultaneous prediction of hair and eye colour from DNA. Forensic Science International Genetics 7(1), 98115

Waterman, A.J. \& Thomas, J.J. 2011. When the bough breaks: Childhood mortality and burial practice in Late Neolithic Atlantic Europe. Oxford Journal of Archaeology 32(2), 165-83

Whitehouse, N.J., Schulting, R.J., McClatchie, M., Barratt, P., McLaughlin, R., Bogaard, A., Colledge, S., Marchant, R., Gaffrey, J. \& Bunting, M.J. 2014. Neolithic agriculture on the European western frontier: The boom and bust of early farming in Ireland. Journal of Archaeological Science 51, 181-205

Whittle, A., Healy, F. \& Bayliss, A. (eds). 2011. Gathering Time: Dating the Early Neolithic enclosures of southern Britain and Ireland. Oxford: Oxbow Books

Williams, H. 2014. A well-urned rest: Cremation and inhumation in early Anglo-Saxon England. In Kuijt et al. (eds) 2014, 93-118

Woodman, P. \& McCarthy, M. 2003. Contemplating some awful(ly interesting) vistas: Importing cattle and red deer into Prehistoric Ireland. In I. Armit, E. Murphy, E. Nelis \& D.A.A. Simpson (eds), Neolithic Settlement in Ireland and Western Britain, 30-9. Oxford: Oxbow Books

Worley, F. \& Serjeantson, D. 2014. Red deer antlers in Neolithic Britain and their use in the construction of Monuments. In K. Baker, R. Carden \& R. Madgwick (eds), Deer and People, 119-31. Oxford: Oxbow Books

Wysocki, M., Griffiths, S., Hedges, R., Bayliss, A., Higham, T., Fernandez-Jalvo, Y. \& Whittle, A. 2013. Dates, diet, and dismemberment: Evidence from the Coldrum megalithic monument, Kent. Proceedings of the Prehistoric Society 79, 6190 
Yang, D.Y., Eng, B., Waye, J.S., Dudar, J.C. \& Saunders, S.R. 1998. Improved DNA extraction from ancient bones using silicabased spin columns. American Journal of Physical Anthropology 105(4), 539-43

\section{[H1]RÉSUMÉ}

[10P]Rites de passage: pratiques mortuaires, dynamique de population et chronologie dans le complexe de tombes à couloir de Carrowkeel, Co. Sligo, Irlande, de Thomas Kador, Lara M. Cassidy, Jonny Geber, Robert Hensey, Pádraig Meehan, et Sam Moore

La première investigation des restes humains du complexe de tombes à couloir de Carrowkeel depuis leur excavation en 1911 a révélé plusieurs nouveaux et importants aperçus de la vie ,la mort et des pratiques funéraires dans l'Irlande néolithique. L'analyse ostéologique a apporté la première preuve concluante de l'occurence de démembrement des morts dans les tombes à couloir irlandaises pratiqué en contemporanéité avec la crémation comme une suite de traitements funéraires.Les rechercrhes ont aussi mis en une série de changements dans la tradition sépulcrale du complexe au cours du néolithique. Le fait de fournir une chronologie pour ces changements permet de les relier à des courants plus étendus de construction de monuments qui pourraient avoir un lien avec des changements à la fois dans l'utilisation de la terre et le climat pendant cette période. De multiples analyses d'isotopes donnent à penser que des individus extérieurs à la région figuraient parmi les personnes enterrées et qu'existaient différentes zones d'approvisionnement en nourriture à la période du néolithique tardif. Les résultats préliminaires de séquences d'ADN ancien apportent des témoignages de généalogie génétique des populations du néolithique irlandais, démontrant leurs origines anatoliennes et des liens le long de la façade atlantique

\section{[H1]ZUSSAMENFASSUNG}

Übergangsriten: Bestattungspraktiken, Bevölkerungsdynamik und Chronologie des Ganggrabkomplexes von Carrowkeel, Co. Sligo, von Thomas Kador, Lara M. Cassidy, Jonny Geber, Robert Hensey, Pádraig Meehan, und Sam Moore

Die erste Untersuchung der menschlichen Überreste aus den Ganggräbern von Carrowkeel seit ihrer Ausgrabung von 1911 erbrachte mehrere neue und wichtige Erkenntnisse über Leben, Sterben und Begräbnispraktiken im neolithischen Irland. Die osteologischen Untersuchungen liefern die ersten sicheren Beweise für das Vorkommen von Zerlegungen von Toten in irischen Ganggräbern, die zeitgleich mit der Leichenverbrennung praktiziert wurde als eines aus einer ganzen Reihe funerärer Verfahren. Die Forschungen bezeugen auch eine Reihe von Veränderungen in den Bestattungstraditionen in diesem Gräberkomplex im Verlauf des Neolithikums. Das Erstellen einer Chronologie für diese Veränderungen ermöglicht es, diese mit weiteren Entwicklungen in der Errichtung der Monumente zu verknüpfen, was wiederum mit Veränderungen sowohl der Landnutzung als auch des Klimas in dieser Zeitspanne verbunden sein mag. Multiisotopen-Analysen deuten auf das Vorhandensein nicht-lokaler Individuen unter den hier Beigesetzten wie auch auf die Nutzung verschiedener Regionen für den Nahrungserwerb im späteren Neolithikum. Vorläufige Ergebnisse der aDNA-Untersuchungen liefern Hinweise auf die genetische Herkunft der neolithischen Populationen Irlands und zeigen ihre anatolische Herkunft sowie Verbindungen entlang der atlantischen Fassade.

\section{[H1]RESUMEN}

Ritos de paso: prácticas mortuorias, dinámicas de población y cronología en el complejo de tumba de corredor Carrowkeel, Co.Sligo, Irlanda, por Thomas Kador, Lara M. Cassidy, Jonny Geber, Robert Hensey, Pádraig Meehan, y Sam Moore

Las primeras investigaciones de los restos humanos del complejo de la tumba de corredor de Carrowkeel, desde su excavación en 1911, han revelado algunos aspectos nuevos e importantes acerca de la vida, la muerte y las prácticas funerarias en el Neolítico irlandés. El análisis osteológico ha proporcionado la primera prueba concluyente de desmembramiento en las tumbas de corredor irlandesas, practicado simultáneamente con la cremación como parte del repertorio de los tratamientos funerarios. Esta investigación también resalta una serie de cambios en la tradición funeraria en el complejo a lo largo del Neolítico. El establecimiento de una cronología para estos cambios permite vincularlos con tendencias más generales en la construcción de este tipo de monumentos, que se pueden relacionar con modificaciones en el uso de la tierra y del clima durante este período. Los análisis multi-isotópicos indican la presencia de individuos no locales entre los enterrados y la existencia de diferentes áreas de abastecimiento de alimentos durante el Neolítico Final. Los resultados preliminares de secuenciación de ADN antiguo proporcionan una evidencia de la ascendencia genética de las poblaciones neolíticas irlandesas, demostrando su origen anatolio y sus vínculos con el resto de la fachada atlántica.

Fig. 1. Overview map of the Carrowkeel complex and the wider Lough Arrow group of monuments (inset: map of Ireland showing location of Carrowkeel)

Fig. 2. Aerial photograph of the Carrowkeel passage tomb complex (Courtesy of the Irish National Monuments Service, Department of Arts, Heritage and the Gaeltacht)

Fig. 3. Figure 3: Simplified geological map of County Sligo (Courtesy of the Geological Survey of Ireland). Inset: detail of the Carrowkeel region with the sample locations for the TELLUS Border vegetation samples (V1-4). 
Fig. 4. Photograph of Cairn F, with R.A.S. Macalister sitting on top, taken by W.A. Green during excavations in June 1911. Note the hand-inked caption reading 'Carrowkeel No. 4 Cairn' (Courtesy of the National Museum of Northern Ireland)

Fig. 5. Examples of human bones with evidence of cut marks (arrows) (a) the neck of a right femur from Cairn K; (b) the base of a right fourth metatarsal from an unknown context; (c) a left calcaneus from an unknown context; (d) a left lateral cuneiform bone from an unknown context

Fig. 6. Fragments of cremated antler from Cairn K (photograph: Jonny Geber)

Fig. 7a. Chronological model for depositions at Carrowkeel in one continuous sequence (with two outliers)

Fig. 7b. (Continued)

Fig. 8a. Chronological model for depositions at Carrowkeel in two phases (with antlers first and two outliers)

Fig. 8b. (Continued)

Fig 9. Strontium concentrations $\&{ }^{87} \mathrm{Sr} /{ }^{86} \mathrm{Sr}$ ratios, showing the diagenetic vectors between enamel $\&$ dentine samples, a possible mixing line between ${ }^{87} \mathrm{Sr} /{ }^{86} \mathrm{Sr} 0.7105$ and 0.7086 , as well as the two outliers (CaK 8_03 \& 09). The dashed horizontal lines demarcate the likely Carboniferous Limestone range. $2 \sigma$ errors are within the symbols

Fig. 10. Oxygen (on dental enamel carbonate) \& strontium isotope results showing a possible mixing line between ${ }^{87} \mathrm{Sr} /{ }^{86} \mathrm{Sr} 0.7105$ and 0.7086 , as well as the two outliers (CaK 8_03 \& 09). The dashed horizontal lines demarcate the likely Carboniferous Limestone range. Errors indicated for $\delta^{18} \mathrm{O}, 2 \sigma$ errors for ${ }^{87} \mathrm{Sr} /{ }^{86} \mathrm{Sr}$ are within the symbols

Fig. 11. Carbon (on dental enamel carbonate) \& strontium isotope results showing a possible mixing line between ${ }^{87} \mathrm{Sr} /{ }^{86} \mathrm{Sr} 0.7105$ and 0.7086 , as well as the two outliers (CaK 8_03 \& 09). The dashed horizontal lines demarcate the likely Carboniferous Limestone range. Errors indicated for $\delta^{13} \mathrm{C}, 2 \sigma$ errors for ${ }^{87} \mathrm{Sr} /{ }^{86} \mathrm{Sr}$ are within the symbols

Corresponding author: Thomas Kador t.kador@ucl.ac.uk

${ }^{1}$ UCL Arts \& Sciences (BASc), University College London, London, UK

Email: t.kador@ucl.ac.uk

${ }^{2}$ Human Population Genetics Laboratory, Trinity College Dublin, Ireland

${ }^{3}$ Department of Anatomy, University of Otago, Dunedin, New Zealand

${ }^{4}$ Glencar, Sligo, Ireland

${ }^{5}$ Shriff, Dromahair, Leitrim, Ireland

${ }^{6}$ Applied Archaeology, Department of Environmental Science, School Science, Institute of Technology, Sligo, Ireland

Running header:

T. Kador et al. MORTUARY PRACTICE, POPULATION DYNAMICS, CHRONOLOGY: CARROWKEEL, CO. SLIGO 